\title{
Customer Satisfaction in the Hotel Industry: A Case Study from Sicily
}

\author{
Gandolfo Dominici (Corresponding author) \\ Facoltà di Economia, Dip. S.E.A.F., Università di Palermo \\ viale delle Scienze ed.13, 90128, Palermo, Italy \\ E-mail: gandolfodominici@unipa.it
}

\section{Rosa Guzzo}

Facoltà di Economia, Università di Palermo, Viale delle Scienze ed.13, 90128, Palermo, Italy

E-mail: rosyguzzo@hotmail.it

\begin{abstract}
In order to be successful in the market it is not sufficient to attract new customers managers must concentrate on retaining existing customers implementing effective policies of customer satisfaction and loyalty. In hotel industry customer satisfaction is largely hooked upon quality of service. A management approach focused on customer satisfaction can improve customer loyalty, thus increasing the positive image of the touristic destination. Hence, exploring the importance for customers of hotel attributes in hotel selection is indispensable. Research on the topic of guest satisfaction, which translates into the consideration of whether or not customers will return to a hotel or advise it to other tourists, is pivotal to the success of the hospitality business. Neglecting to pay attention to those hotel attributes considered most important by guests, may lead to negative evaluation of the hotel, thus restricting the chance of repeat patronage. We perform a qualitative analysis of a large hotel in Sicily (IT), the Sporting Club Hotel in the town Cefalù, using the Critical Incident Approach (Hayes, 2008). Through the analysis of this case we evaluate the overall customer satisfaction level for the hotel and for each service supplied. We conclude discussing the result and proposing improvement in customer satisfaction management of the hotel.
\end{abstract}

Keywords: Customer satisfaction, Hotel industry, Service marketing

According to Italian regulation on research evaluation paragraphs 1, 2, and 3 are attributed to dr. Gandolfo Dominici; paragraphs 4 and 5 to dr. Rosa Guzzo.

\section{Introduction}

Customer satisfaction is a business philosophy which tends to the creation of value for customers, anticipating and managing their expectations, and demonstrating ability and responsibility to satisfy their needs. Quality of service and customer satisfaction are critical factors for success of any business (Gronoos, 1990; Parasuraman et al., 1988). As Valdani (2009) points out: enterprises exist because they have a customer to serve. The key to achieve sustainable advantage lies in delivering high quality service that results in satisfied customers (Shemwell et al, 1998). Service quality and customer satisfaction are key factors in the battle to obtain competitive advantage and customer retention. Customer satisfaction is the outcome of customer's perception of the value received in a transaction or relationship, where value equals perceived service quality, compared to the value expected from transactions or relationships with competing vendors (Blanchard \& Galloway, 1994; Heskett et al., 1990; Zeithaml et al., 1990). In order to achieve customer satisfaction, it is important to recognize and to anticipate customers' needs and to be able to satisfy them. Enterprises which are able to rapidly understand and satisfy customers' needs, make greater profits than those which fail to understand and satisfy them (Barsky \& Nash, 2003). Since the cost of attracting new customers is higher than the cost of retaining the existing ones, in order to be successful managers must concentrate on retaining existing customers implementing effective policies of customer satisfaction and loyalty. This is especially true in the hotel industry.

Nowadays one of the biggest challenges for managers in the hotel industry is to provide and sustain customer satisfaction. Customer requirements for quality products and service in the tourism industry has become increasingly evident to professionals (Lam \& Zhang, 1999; Yen \& Su, 2004). Guest relationships are a strategic asset of the organization (Gruen et al., 2000) and customer satisfaction is the starting point to define business objectives. In this context, positive relationships can create customer's higher commitment and increase their return rate. Long-term and reciprocally advantageous relationships between customers and the hotel is becoming progressively important because of the highly positive correlation between guests' overall satisfaction levels and 
the probability of their return to the same hotel (Choi \& $\mathrm{Chu}, 2001$ ). Hotels are increasing their investments to improve service quality and the perceived value for guests so as to achieve better customer satisfaction and loyalty, thus resulting in better relationships with each customer (Jones et al., 2007). Relationship quality has a remarkable positive effect on hotel guests' behavior: it creates positive word of mouth (WOM) and increments repeated guest rates (Kim et al., 2001).

In this paper, after a review of the main literature on customer satisfaction and retention in the hotel industry, we confront a real case (Hotel Sporting Club of Cefalù, Sicily, Italy) and analyze, using a qualitative methodology, whether there is a positive correlation between the customer oriented business philosophy, adopted by the management of Sporting Club, and the achievements obtained in terms of customer satisfaction. We study the case of Sporting Club Hotel using the critical incident approach (Hayes, 2008) with semi-structured and unstructured interviews (Lindlof \& Taylor, 2002), that we performed to both management and customers. Our empirical study gathers information by the combined use of different interview methodologies in order to evaluate the influence of customer oriented business philosophy on customer satisfaction. We analyze the results to highlight eventual gaps among managers' expectation and results and to evaluate the overall customer satisfaction level for the hotel and the specific one for each service supplied. We conclude discussing the results and proposing improvements in customer satisfaction management for the hotel.

\section{Literature overview}

In the past, tourism has been often considered as the natural outcome of environmental and cultural resources of a specific territory. In this view, the role of hospitality enterprises cannot influence demand levels and is merely limited to the supply of services to tourists. Le Blanc \& Nguyen (1996) suggest that marketing efforts should be directed to highlight the environmental characteristics of the location in order to attract new customers. The constant increase of demand of touristic services, and the request for higher standards by the guests, has enforced the competition among hospitality suppliers and highlighted how the attractivity of the touristic destination is influenced by the standards of the services provided by the local hotels.

In this scenario, providing high quality services and improving customer satisfaction are widely recognized as fundamental factors boosting the performances of companies in the hotel and tourism industry (Barsky \& Labagh, 1992; Le Blanc, 1992,; Le Blanc et al., 1996; Stevens et al., 1995, Opermann, 1998). Hotels with good service quality will ultimately improve their profitability (Oh \& Parks, 1997). In a competitive hospitality industry which offers homogeneous services, individual hoteliers must be able to satisfy costumers better then their counterparts (Choi \& Chou, 2001).

To obtain loyalty and to outweigh other competitors, hotel providers must be able to obtain high levels of customer satisfaction for the service supplied. There are several studies that analyze the needs and the desires of tourists. A research by Wuest et al. (1996) defined the perception of hotel attributes as the degree to which guests may find various services and facilities critical for their stay in a hotel. Hotel's attributes such as cleanliness, price, location, security, personal service, physical attractiveness, opportunities for relaxation, standard of services, appealing image, and reputation are recognized as decisive by travelers to assess the quality of the hotel (Atkinsons, 1988; Ananth et al., 1992; Barsky \& Labagh, 1992; Cadotte \& Turgeon, 1988; Knutson, 1988; McCleary et al., 1993; Rivers et al., 1991; Wilensky \& Buttle, 1988).

According to a survey carried out by Barsky \& Nash in 2006, regarding the main hotel chains worldwide, between 2002 and 2005, the importance of loyalty programs for guest's decision on where to stay increased from $32 \%$ to $34 \%$.

Although the search for new locations is certainly the most important factor for many tourists, several studies highlighted that there is a good portion of customers that chose to repeat their holidays' destination, showing a certain degree of loyalty (Oppermann, 1998; Fyall et al., 2003). These studies on tourists' loyalty indicate five main factors which affect the repetition of the trip to the same tourist place:

the desire to reduce the risk of making a mistake when choosing an alternative destination;

the chance to meet the same people again ;

the emotional affection to a specific place;

the possibility to explore the place better ;

the desire to show the place to other people.

Hoteliers need to fully acknowledge which service attributes are most likely to influence customers' choice intentions (Richard \& Sundaram, 1993). Customer satisfaction practices can help them to identify the crucial 
elements affecting customers' purchase experience and post-purchase behavior such as subsequent purchase and favorable word of mouth (WOM) publicity (Berkman \& Gilson, 1986; Choi \&Chu, 2001; Fornell, 1992; Halstead \& Page, 1992; Knutson, 1988; Pizam, 1994). A satisfied guest promotes positive WOM at no cost for the enterprise and with effect and credibility that are superior to those of conventional advertising (Lee et al., 2006, Tarn, 2005, Villanueva et al., 2008). WOM effect is also amplified by the World Wide Web (Dominici, 2009; Trusov et al. 2009).

Customer satisfaction is the starting point to build customer loyalty, therefore a long-term relationship. This creates a loyalty's stock in the enterprise which improves corporate image. The consolidation of relations with guests leads to repeated patronage. On the other hand, an unsatisfied customer may represent a danger for the enterprise. A research, conducted by Cherubini (1997), shows that only $4 \%$ of unsatisfied customers complains to the business explaining the reason of their unsatisfaction, and each client who doesn't officially complain generates a negative WOM which can involve also 1000 people.

Hence, both exploring the importance for customers of single attributes in hotel selection and to systematically survey their level of satisfaction are indispensable. Research on the topic of guest satisfaction, which translates into the consideration of whether or not customers will return to a hotel or advise it to other tourists, is pivotal to the success of the hospitality business. Neglecting to pay attention to those hotel attributes considered most important by guests leads to negative evaluations of the hotel, thus restricting the chance of repeat patronage.

\section{Methodology}

Measuring customer satisfaction in the hotel industry is important in order to:

know guests' opinions. Each guest has different expectations about hospitality services, thus it is important to know their impressions not only by aggregated statistics but also singularly;

determine the expectations, the needs and the requests of customers;

overcome the gaps between customers' expectation and services offered;

supervise the operations of the enterprise as a system.

Guests' loyalty represents a homogeneous cluster which can be measured using behavioral and attitudinal variables.

In our analysis we focus on a large hotel in Cefalù on the Sicilian coast in the south of Italy. We performed the survey during the summer of 2008. In our survey we used both field and desk research methodology.

We started with a "desk" analysis and then we administered a survey to both hotel managers and guests; then we cross checked the information obtained. In chronological order we proceeded to:

analyze the corporate web-page and visit the location in order to verify the truthfulness of the information supplied to customers;

interview the management of the hotel to verify the existence of a customer oriented philosophy;

administer a questionnaire to the director of the village to confirm the results of the interview;

administer questionnaires to 100 guests (on 122 we attempted to interview) of the hotel using the Critical Incident Approach (Hayes, 2008).

The Critical Incident Approach focuses on obtaining information from customers about the services and goods they encountered in the past. This approach can be used both for customers and staff.

For our analysis we submitted semi-structured interviews to guests. We prepared an interview guide based on the desk research regards the company web-page and their promotional material.

A semi-structured interview is a flexible interview methodology, allowing new questions to be brought up during the interview as a result of what the interviewee says. The flexibility given to answers by this interview methodology gave us the possibility to shed light on particular needs of customers which may not have been perceived by the management. The incidents are then employed to create classes of satisfaction items based on shared common words, used in the incident statement. These satisfaction items are then applied to detect crucial customer quality requirements.

Using the Critical Incident Approach, we interviewed 100 customers with semi-structured interviews, asking each of them to describe 5 positive and 5 negative aspects of the overall service offered by the hotel. The 5 positive aspects are: organization; kids' club; number of services provided; family atmosphere; good entertainment. The 5 negative aspects found are: excursion prices (for some excursions); beach tidiness; 
insufficient shuttle service for Cefalù; room service; room tidiness and comfort.

We then used semi-structured interviews for the questionnaires about the quality of each service and we administered it to the same target. We classified 52 verbal expressions used by guests to describe specific services supplied (appendix - table1). Using the information gathered administering the interviews, we determined the level of customer satisfaction for each service supplied.

To verify the existence of a real customer oriented approach on behalf of the management, we compared, for each service supplied by the hotel, the results regards the perceptions of the quality of services of the management with those of the guests.

\section{Analysis and results}

From the unstructured interviews administered to the management, it emerged that Sporting Club Hotel's target are families. Families are considered by the hotel's management the ideal target because they are more sensitive to customer loyalty policies. The hotel has a good repeated patronage rate with $20 \%$ of guests that have already spent their holidays in the hotel in the past. The hotel works especially during summer and national holidays and gives several possibilities of trips to visit the main touristic attractions in Sicily. In 2008 it had about 35.000 guests. Desk analysis shows that the corporate vision refers specifically to customer satisfaction.

Desk analysis and unstructured interviews to management show that customer loyalty programs are promoted and managed by the management and in particular by the head of the marketing office. The main promotion channels are:

distribution of promotional material through travel agencies;

experience trips, where local tour operators, press, opinion leaders are invited to visit the hotel;

Web-page;

TV programs to describe the hotel;

participation to fairs;

public relations.

The services examined using the semi-structured interviews are:

overall service perception;

transfer service;

reception service;

room quality;

restaurant service;

trips and excursions service;

seaside service;

entertainment.

Respondents were asked to describe 5 positive and 5 negative aspects about the overall service perception, and could answer with minimum 1 to maximum 2 phrases for each question for the specific services (from 2 to 8 of the list above). Verbal expressions obtained have been first grouped by service questioned (table 1 of the appendix) and expression and then classified according to the judgment of the expression when the interviewee was asked about the service. The tables 2 to 9 (appendix) show the results of the semi-structured interviews regarding the attributes and expressions used by interviewees.

What emerges from the semi-structured interviews is an overall positive customer satisfaction level. The main strengths of the hotel are: the restaurant, the entertainment program and the organization; the weaknesses are the beach and the rooms.

We compare the results about the managers' perceptions of quality of the hotel's services of the management with those of guests, using the Customer Satisfaction Convergence Matrix (Cuomo, 2000).

\section{Figure 1. here}

In the case analyzed both management and customers have an overall positive perception, so we can assert that the management has a realistic perception of the level of customer satisfaction. 


\section{Conclusions}

Our qualitative analysis of the Sporting Hotel of Cefalù (IT) shows that the level of customer satisfaction is good both considering the overall evaluation and the single services (6 out of 8 of the single aspects examined). Human resource management in particular results to be specially effective in entertainment and restaurant service.

By interviewing the hotel's management about the results, it emerged that they didn't have the perception of the gaps we found in beach and room services. Though the latter service heavily depends on the quality of the hotel's structure, a certain degree of improvement maybe obtain through a concrete effort towards their customization.

In general, the main factor which limits the Sporting Club Hotel's ability to achieve higher customer satisfaction levels is the standardization of services that reduces the possibility to customize the offer for specific guest needs. Indeed, from the unstructured interviews to the hotel's management it became apparent that the organizations adopts a "push" marketing approach. The offer of touristic services is decided by the management and not in collaboration with customers nor considering their specific needs. Moreover customer satisfaction is not used to differentiate the services supplied.

Another weakness of the customer satisfaction management system of the hotel is that a structured CRM (Customer Relationship Management) system has not yet been implemented. Even if a customer database exists, the data collection is not even planned, and the data gathered can't be easily found and used by management for marketing decisions. Any benchmarking information about customer satisfaction levels is missing, so the management doesn't have a clue about what competitors are doing.

The Sporting Club hotel has a good potential to satisfy customers and compete, but to improve its customer satisfaction standards the management needs to adopt new and more advanced CRM procedures. The decision process about the key issues regarding customer satisfaction, should not be based only on accounting and cost data, but also on a customer database created ad hoc.

Even if the case we studied has been chosen because it is representative of other similar businesses in the area, the main limit of this research is that it is circumscribed to only one hotel. We plan in the near future to make other qualitative analysis on other hotels in the same area and compare the results in order to obtain a wider view about customer satisfaction in Sicilian hotels.

\section{References}

Ananth M., DeMicco F.J., Moreo P.J., \& Howey R.M. (1992). Marketplace lodging needs of mature travelers. The Cornell Hotel and Restaurant Administration Quarterly, 33 (4): 12-24.

Atkinson A. (1988). Answering the eternal question: what does the customer want?. The Cornell Hotel and Restaurant Administration Quarterly, 29 (2): 12-14.

Barsky J., \& Labagh R. (1992). A strategy for customer satisfaction. The Cornell Hotel and Restaurant Administration Quarterly 35 (3): 32-40.

Barsky J., \& Nash L. (2003). Customer satisfaction: Applying concepts to industry- wide measures. The Cornell Hotel and Restaurant Administration Quarterly, 44 (4): 173-183.

Barsky, J., \& Nash L. (2006). Companies update loyalty programs, increase effectiveness. Hotel \& Motel Management, 22(11): 28-29.

Berkman H.W., \& Gilson C. (1986). Consumer Behavior: Concepts and Strategies, 3rd ed., Kent, Boston.

Blanchard R.F., \& Galloway R.L. (1994). Quality in retail banking. International Journal of Service Industry Management, 5 (4): 5-23.

Cadotte E.R., \& Turgeon N. (1988). Key factors in guest satisfaction. The Cornell Hotel and Restaurant Administration Quarterly, 45-51.

Choi T. Y., \& Chu R. (2001). Determinants of hotel guests' satisfaction and repeat patronage in Hong Kong hotel industry. International Journal of Hospitality Management, 20: 277-297.

Cuomo M. T. (2000). La Customer Satisfaction, vantaggio competitivo e creazione di valore. Cedam, Padua.

Dominici G. (2009). E-Marketing. Analisi dei cambiamenti dai modelli di business al mix operativo, FrancoAngeli, Milan.

Fornell C. (1992). A national customer satisfaction barometer: the Swedish experience. Journal of Marketing, 56: $6-21$. 
Fyall A., Callod C., \& Edwrds B. (2003). Relationship Marketing: The Challenge for Destinations. Annals of Tourism, 30 (3): 644-659.

Gronoos, C. (1990). Service management and marketing: managing the moments of truth in service competition. Lexington Books, USA.

Gruen T. W., Summers J. O., \& Acito, F. (2000). Relationship marketing activities, commitment, and membership behaviors in professional associations. Journal of Marketing, 64 (3): 34-49.

Halstead D., \& Page Jr. T.J. (1992). The effects of satisfaction and complaining behavior on consumers repurchase behavior. Journal of Satisfaction, Dissatisfaction and Complaining Behavior, 5: 1-11.

Hayes B. E. (2008). Measuring Customer Satisfaction and Loyalty, $3^{\text {rd }}$ edition, ASQ Quality Press, Milwaukee, USA.

Heskett J.L., Sasser W.E., \& Hart C.W.L. (1990). Breakthrough Service. The Free Press, New York.

Jones D. L., Mak B., \& Sim J. (2007). A New Look at the Antecedents and Consequences of Relationship Quality in the Hotel Service Environment. Services Marketing Quarterly, 28(3): 15-31.

Kandampully J., \& Suhartanto D. (2000). Customer loyalty in the hotel industry: the role of customer satisfaction and image. International Journal of Contemporary Hospitality Management, 12 (6): 346-351.

Kim W. G., Han J. S., \& Lee E. (2001). Effects of relationship marketing on repeat purchase and word of mouth. Journal of Hospitality \& Tourism Research, 25 (3): 272-288.

Knutson B. (1988). Frequent travelers: making them happy and bringing them back. The Cornell Hotel and Restaurant Administration Quarterly, 29 (1): 83-87.

Kotler P., Bowen J.T., \& Makens J.C. (2010). Marketing for Hospitality and Tourism $5^{\text {th }}$ edition, Pearson.

Lam T., \& Zhang H. (1999). Service quality of travel agents: the case of travel agents in Hong Kong. Tourism Management, 20: 341-349.

LeBlanc G. (1992). Factors affecting customer evaluation of service quality travel agencies: an investigation of customer perceptions. Journal of Travel Research 30 (4): 10-16.

LeBlanc G., \& Nguyen N. (1996). An examination of the factors that signal hotel image to travelers. Journal of Vacation Marketing 3 (1): 32-42.

Lee J., Lee J., \& Feick L. (2006). Incorporating word-of-mouth effects in estimating customer lifetime value. Journal of Database Marketing \& Customer Strategy Management; 14 (1): 29-39.

Lindlof T. R., \& Taylor B. C. (2002). Qualitative communication research methods $2^{\text {nd }}$ edition. SAGE Publications.

McCleary K.W., Weaver P.A., \& Hutchinson J.C. (1993). Hotel selection factors as they relate to business travel situations. Journal of Travel Research, 32 (2): 42-48.

Parasuraman A., Zeithaml V., \& Berry L. (1988). SERVQUAL: a multiple-item scale for measuring consumer perceptions of service quality. Journal of Retailing, 64 (1): 12-40.

Oh H., \& Parks, S.C. (1997). Customer satisfaction and service quality: a critical review of the literature and research implications for the hospitality industry. Hospitality Research Journal, 20 (3): 35-64.

Oppermann M. (1998). Destination Threshold Potential and the Law of Repeat Visitation, Journal of Travel Research, 37 (2): 131-137.

Pizam A. (1994). Monitoring customer satisfaction, in: Davis, B., Lockwood, A. (eds.), Food and Beverage Management: A Selection of Readings, Butterworth-Heinemann, London.

Richard M.D., \& Sundaram D.S. (1993). Lodging choice intentions: a causal modeling approach. Journal of Hospitality and Leisure Marketing, 1 (4): 81-98.

Rivers M.J., Toh R.S., \& Alaoui M. (1991). Frequent-stayer programs: the demographic, behavioral, and attitudinal characteristics of hotel steady sleepers. Journal of Travel Research, 30 (2): 41-45.

Shemwell, D.J., Yavas, U., \& Bilgin, Z. (1998). Customer-service provider relationship: An empirical test of a model of service quality, satisfaction and relationship-oriented outcome. International Journal of Service Industry Management, 9: 155-168.

Tarn D. (2005). Marketing-based tangibilisation for services. Service Industries Journal; 25 (6): 747-772. 
Trusov M, Bucklin R., \& Pauwells K. (2009). Effects of Word-of-Mouth Versus Traditional Marketing: Findings from an Internet Social Networking Site. Journal of Marketing, 73 (5): 90-102.

Valdani E. (2009). Cliente \& Service Management, Egea, Milan.

Villanueva J., Yoo S., \& Hanssens D. (2008). The Impact of Marketing-Induced Versus Word-of-Mouth Customer Acquisition on Customer Equity Growth. Journal of Marketing Research (JMR),45 (1): 48-59.

Vijayadurai, J. (2008). Service Quality, Customer Satisfaction and Behavioural Intention in Hotel Industry. Journal of Marketing \& Communication, 3(3): 14-26.

Wilensky L., \& Buttle F. (1988). A multivariate analysis of hotel benefit bundles and choice trade-offs. International Journal of Hospitality Management, 7 (1): 29-41.

Wuest B.E.S., Tas R.F., \& Emenheiser D.A. (1996). What do mature travelers perceive as important hotel/ motel customer service?, Hospitality Research Journal, 20 (2): 77-93.

Yen A., \& Su L. (2004). Customer satisfaction measurement practice in Taiwan hotels. Hospitality Management, 23: 397-408.

Zeithaml V., Parasuraman A., \& Berry L.L. (1990). Delivering Quality Service. The Free Press, New York. 


\section{Appendix}

Table 1. The numbers in the tables correspond to the expression in table 1 .

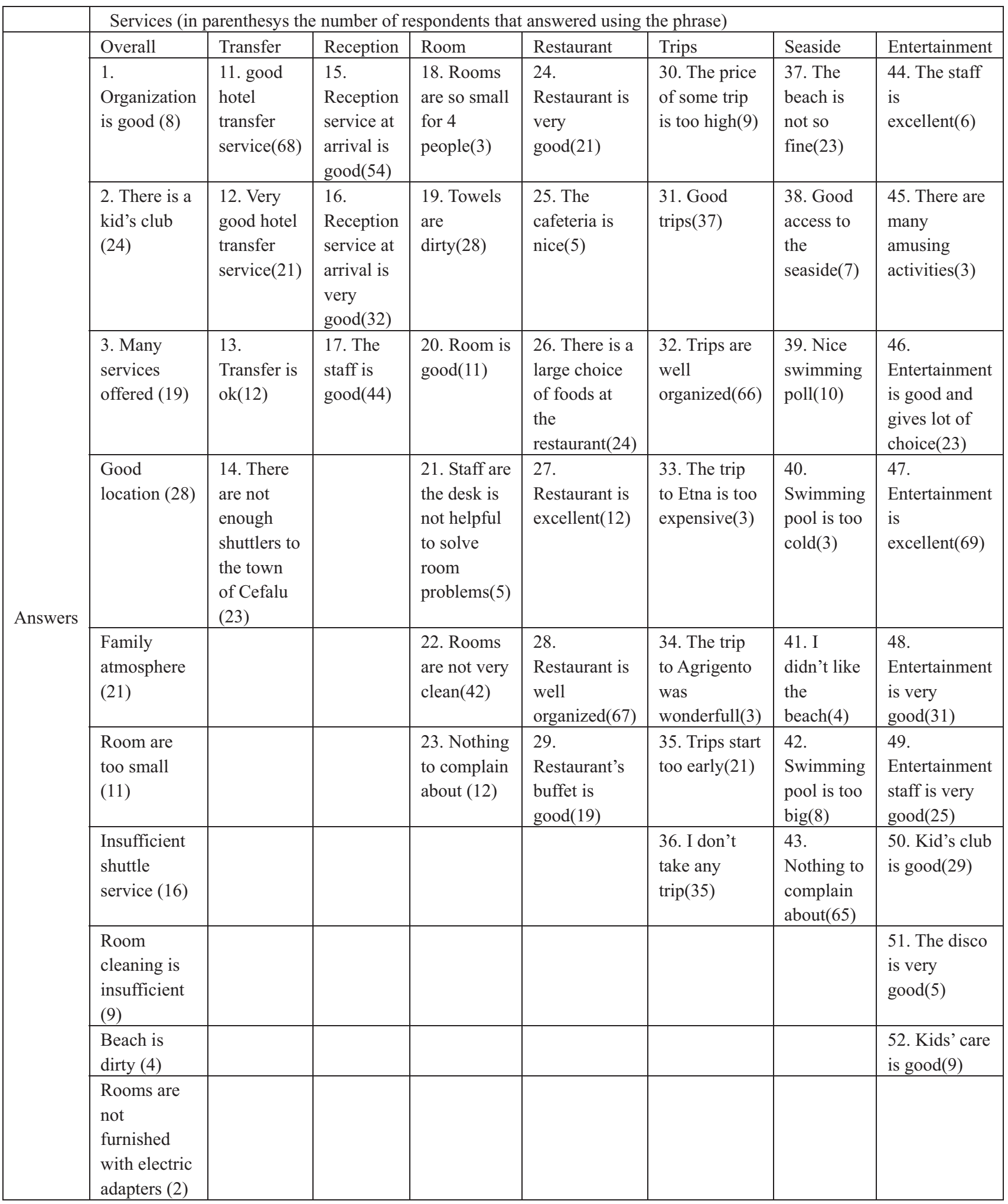


Table 2.

Table 3.

\begin{tabular}{|c|c|c|c|}
\hline \multicolumn{4}{|c|}{ OVERALL SERVICE PERCEPTION } \\
\hline judgment & Very good & Good & Not good \\
\hline expressions & $2,4,5$ & 1,3 & $6,7,8,9,10$ \\
\hline$N$ of answers & 73 & 27 & 42 \\
\hline
\end{tabular}

\begin{tabular}{|c|c|c|c|c|c|c|}
\hline \multicolumn{7}{|c|}{ TRANSFER SERVICE } \\
\hline \multicolumn{3}{|c|}{ Transfer to the Hotel } & \multicolumn{3}{c|}{ Shuttle service } \\
\hline judgment & Very good & Good & Not good & Very good & Good & Not good \\
\hline expressions & 12 & 11,13 & & & & 14 \\
\hline$N$ of answers & 21 & 80 & & & & 23 \\
\hline
\end{tabular}

Table 4.

\begin{tabular}{|c|c|c|c|}
\hline \multicolumn{4}{|c|}{ RECEPTION SERVICE } \\
\hline judgment & Very good & Good & Not good \\
\hline expressions & 16 & 15,17 & \\
\hline$N$ of answers & 32 & 98 & \\
\hline
\end{tabular}

Table 5.

\begin{tabular}{|c|c|c|c|c|c|c|}
\hline \multicolumn{7}{|c|}{ ROOM QUALITY } \\
\hline \multicolumn{3}{|c|}{ Service quality } & \multicolumn{3}{c|}{ Comfort } \\
\hline judgment & Very good & Good & Not good & Very good & Good & Not good \\
\hline expressions & & & $19,21,22$ & & 20 & 18 \\
\hline$N$ of answers & & & 75 & & 11 & 3 \\
\hline
\end{tabular}

Expression 23 is neutral

Table 6.

Table 7.

\begin{tabular}{|c|c|c|c|}
\hline \multicolumn{4}{|c|}{ RESTAURANT SERVICE } \\
\hline judgment & Very good & Good & Not good \\
\hline expressions & 24,27 & $25,26,28,29$ & \\
\hline$N$ of answers & 33 & 115 & \\
\hline
\end{tabular}

\begin{tabular}{|c|c|c|c|}
\hline \multicolumn{4}{|c|}{ TRIPS AND EXCURSIONS SERVICE } \\
\hline judgment & Very good & Good & Not good \\
\hline expressions & 34 & 31,32, & $30,33,35$ \\
\hline$N$ of answers & 3 & 103 & 33 \\
\hline
\end{tabular}

Expression 36 is neutral 
Table 8.

\begin{tabular}{|c|c|c|c|c|c|c|}
\hline \multicolumn{7}{|c|}{ SEASIDE SERVICE } \\
\hline \multicolumn{3}{|c|}{ Swimming pool } & \multicolumn{3}{c|}{ Beach } \\
\hline judgment & Very good & Good & Not good & Very good & Good & Not good \\
\hline expressions & 42 & 39 & 40 & & 38 & 37,41 \\
\hline$N$ of answers & 8 & 10 & 3 & & 7 & 27 \\
\hline
\end{tabular}

Expression 43 is neutral

Table 9.

\begin{tabular}{|c|c|c|c|c|c|c|}
\hline \multicolumn{7}{|c|}{ ENTERTAINMENT } \\
\hline General entertainment & \multicolumn{3}{c|}{ Kids' club } \\
\hline judgment & Very good & Good & Not good & Very good & Good & Not good \\
\hline expressions & $47,48,49,51$ & 45,46 & & 44 & 50,52 & \\
\hline$N$ of answers & 130 & 26 & & 6 & 38 & \\
\hline
\end{tabular}

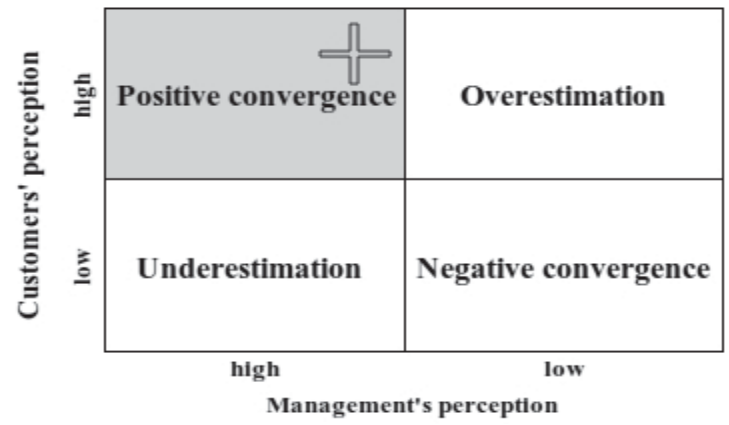

Figure 1. 